\title{
アブラナ科野菜根こぶ病防除手段としての 中間萎调株の間引き作業
}

\author{
宮田善 雄 \\ (京都府立大学農学部)
}

Plasmodiophora brassicae に起因する アブラナ科 野菜根乙ぶ病は最も重要な病害のひとつではあるが, その防除は，てれまで特効薬ともいえる PCNB 剤に 依存してきた。しかし，その残留量の増大は使用制限 を要する段階に達し, ようやく耕種的手段を組み合せ た総合防除システムに関する検討 ${ }^{1)}$ が全国で活発に行 なわれはじめた．そのような手段のひとつに，罹病株 の除去がある. この作業は古来, 間引き作業に付随し て実施されてきたことではあるが，昨今の作付体系の 変化や省力化の風潮の中にあって, ともすれば省略さ れがちである.しかし, 本病原菌のように, おびただ しい数の耐久型胞子を根てふ内に形成して土中に残留 する性質をもつものにおいては，乙の根こぶの除去ほ ど重要かつ有効な手段はないと言ってよい. 演者はさ きにこの作業は一連の農作業の中に明確にシステム化 されるべきであることを指摘した ${ }^{2)}$ が， そのために は, 罹病株を間違いなく判定して, 有效に除去し, し かも, それらが決して商品価值をもつ生産物とはなり 得なかったことの保証が必要であると考えた。

そこで, 1979年秋, 八クサイを用い, 石灰䇪素と殺 菌㓮の混用効果を調べる実験と併行して, それらに関 する予備実験を行ない, 萎淍程度が根とぶ状態の查定 に有效であることを知った。ささらに，1980年秋，本学 農学部学生多数の協力を得て, 栽培経験の有無にかか わらず，萎淍による根こぶの判定と除去が的確に行な われるかどうかの確認試験を丰施した. 囷場として, 本学付属農場の自然污染地域の一部を用い, 巾90cm,

第 1 表 根乙ぶ病調査における時期と項目の相関

\begin{tabular}{|c|c|c|c|}
\hline \multirow{2}{*}{ 判定項目 } & 判 & 時 & 期 \\
\hline & 20日目 & 40日目 & 80日目 \\
\hline 罹 病 率(\%) & $-0.755^{* * *}$ & $-0.475^{*}$ & 0.154 \\
\hline 罹 病 指 数 & $-0.769^{* * *}$ & $-0.663^{* * *}$ & -0.357 \\
\hline 葉部重量 ( g ) & -0.038 & $0.641^{* * *}$ & 〈規準〉 \\
\hline 根部重量 ( g ) & $-0.751^{* * *}$ & $-0.490^{* *}$ & 測定不能 \\
\hline
\end{tabular}

1979年度試験 (24区，個体数15 20/区)

数值は 80 日目葉部重量 (収量) に対する相関係数 $* * *$ : 有意水準 $0.1 \%, * *: 0.5 \%, *: 1 \%$
長さ $25 \mathrm{~m}$ のうね 3 本に, ハクサイ（品種無双）を 2 条 に面播きし, ほぼ慣行通りの栽培を行なった。根てぶ 状態の判定は, 栽培中期に安定する（第 1 表）ことが わかったので，栽培中期にあたる10月16日（52日目） の晴天日に, 全株を対象に萎调程度を 0 〜 34 段階 （第 1 図）に查定し，その半数は引き拢いて根てぶ状 態を調べ, 残りの半数は収穫期(12月 2 日，99日目)ま で育てて追跡調査した. その結果 (第 2 表), 萎调程度 から根てぶ程度を査定するととは極めて有効であり, しかも，萎调程度 $2 \sim 3$ と查定された株は，たとえ 栽培を続けても結球に至ることはなく，その上根とぶ の多くは腐敗して除去不能となっているてとが多かっ た.これに対し，中期萎调株の引き抜きでは，形成さ れている根てぶの $82.7 \%$ 除去するてとができること がわかった．これらの除去株は等量の土と共に大型ポ リエチレン袋に納めて, $1 \sim 2$ カ月放置し, 腐敗が充 分に進んだとてろで, クロルピクリンなどの土壌燻蒸 剤を滴下して密封し, 滅菌する. 夏期はそのままで太 陽熱滅菌されている. これらは堆肥として再利用可能 であり，確認実験遂行中である.

参考文献 1), 第10回土壌伝染病談話会講演要旨集 および現地検討会資料，2），宮田善雄他（1979）京府 大農場報 $9: 6-18$.

第 2 表 萎调・根こぶ程度と収量の関係

\begin{tabular}{|c|c|c|c|c|c|c|c|}
\hline \multirow{2}{*}{$\begin{array}{l}\text { 萎调 } \\
\text { 程度 }\end{array}$} & \multirow{2}{*}{ 調査 } & \multicolumn{4}{|c|}{ 根乙ぶ程度 } & \multirow{2}{*}{ 罹病指数 ${ }^{2)}$} & \multirow{2}{*}{$\begin{array}{c}\text { 平均 } \\
\text { 収量 } \\
\text { (g) }\end{array}$} \\
\hline & & 0 & 1 & 2 & 3 & & \\
\hline \multirow{2}{*}{0} & 中 期 & $67^{*}$ & 32 & 6 & 4 & 17.1 & \\
\hline & 収穫期 & 25 & 18 & 33 & 31 & 55.1 & 1220.0 \\
\hline \multirow{2}{*}{1} & 中 期 & 27 & 40 & 15 & 9 & 35.5 & \\
\hline & 収穫期 & 12 & 24 & 17 & 48 & 66.7 & 983.8 \\
\hline \multirow{2}{*}{2} & 中 期 & 2 & 4 & 17 & 29 & 80.1 & $\longrightarrow$ \\
\hline & 収穫期 & 0 & 2 & 6 & 50 & 94.2 & 365.6 \\
\hline \multirow[b]{2}{*}{3} & 中 期 & 0 & 0 & 0 & 61 & 100.0 & 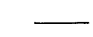 \\
\hline & 収穫期 & 0 & 0 & 0 & 59 & 100.0 & 45.6 \\
\hline
\end{tabular}

本実験には付属農場寺田友良・今井俊夫技師ならびに農学科学生79名の協力を得た. 記して謝意を表する. 

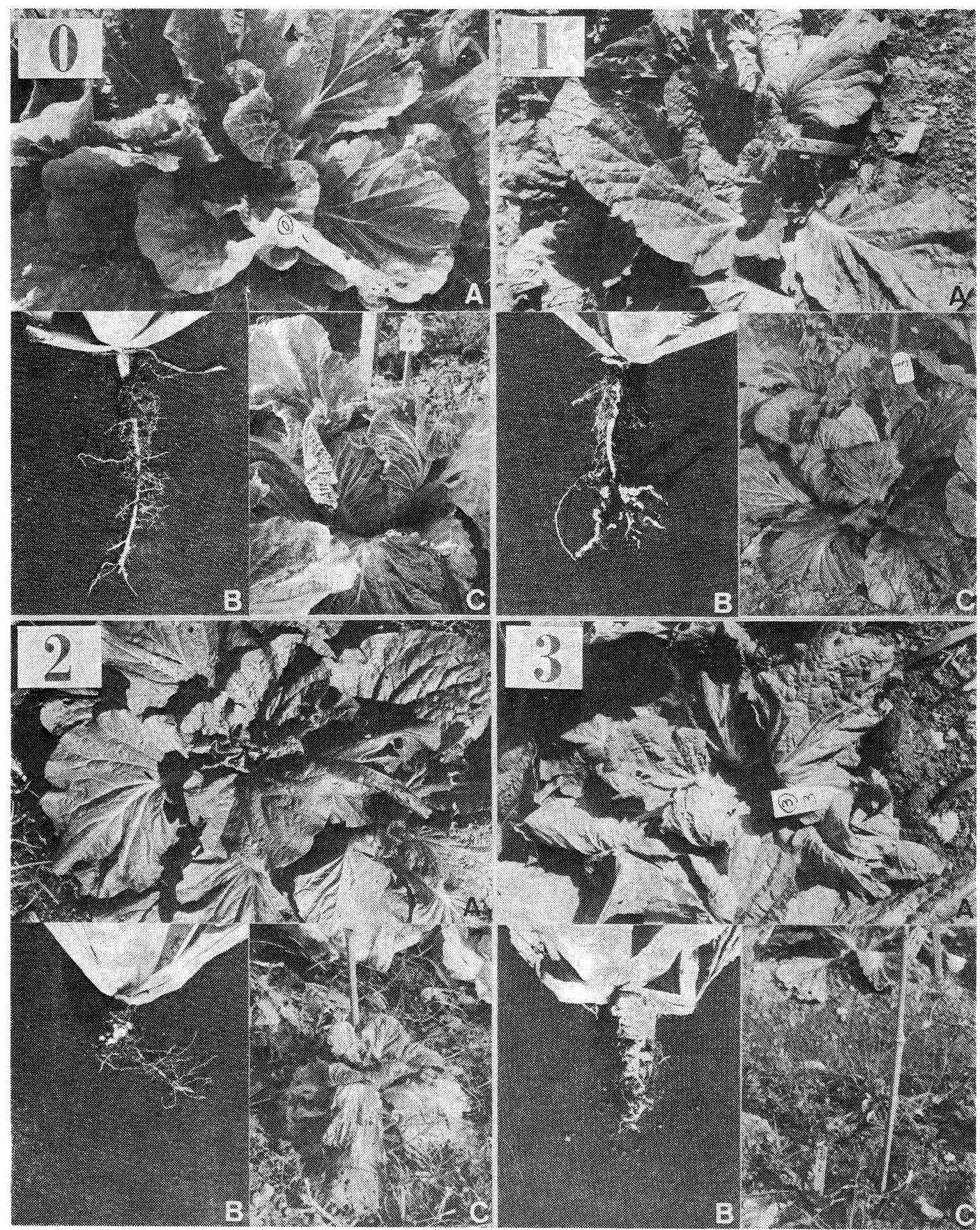

第1図＼cjkstart菱淍程度と根とぶ程度扔よびその後の生育状態

$0-3$ : 程度を表わす数值. $\mathrm{A}$ ：萎调程度 $(0$ : 萎调はみら机ない， 1 : 下葉が萎调.

$2 ：$ ほとんどの展開葉が萎调。 3 : 未展開葉まで萎调） B：根とぶ程度 ${ }^{2)}$

$\mathrm{C}:$ 代表的収穫時の状態 